\title{
A POESIA DO CORPO: A DEFESA DE UMA MORAL AUSTERA*
}

\author{
Elizabeth de Almeida Silvares Pompêo de Camargo*
}

RESUMO: O objetivo deste texto é o estudo das proposições feitas por Fernando de Azevedo relativamente à educação brasileira, em seu primeiro trabalho intelectual, produzido em 1915 e intitulado $A$ poesia do corpo. O autor apresentou este texto em 1916 na forma de tese de concurso para a vaga de professor da cadeira de Ginástica e Educação Física no Ginásio Mineiro. Sem postular qualquer espécie de determinismo, objetiva-se verificar a existência de "tendências e conflitos" que possam ter marcado sua futura produção intelectual. Neste texto, especificamente, examina-se como aparece para Fernando de Azevedo e outros intelectuais da época, tais como Olavo Bilac, Coelho Neto, Euclides da Cunha e Monteiro Lobato, o tema do "rebaixamento do nível moral" no país.

Palavras-chave: Fernando de Azevedo. Pensamento social brasileiro. Instrução pública. Educação moral e organicismo. Educação física.

THE POETRY OF THE BODY: THE DEFENSE OF AN AUSTERE MORALITY

ABSTRACT: This paper studies the proposals concerning Brazilian education made by Fernando de Azevedo in his first intellectual work, A poesia do corpo (The poetry of the body), written in 1915. This author presented his text in 1916 in the form of a dissertation for the competitive examination for the title of professor at the Chair of Ginástica e Educação Física (Gymnastics and Physical Education) of the Ginásio Mineiro. Avoiding any kind of determinism, the text strives to verify the presence of "trends

* O texto faz parte da dissertação de mestrado apresentada em 1995 na Faculdade de Educação da Universidade Estadual de Campinas (UNICAMP), sob o título A militância de Fernando de Azevedo na educação brasileira: a educação física (1915).

* Professora do Departamento de Ciências Sociais Aplicadas à Educação, da Faculdade de Educação da UNICAMP.

Disponível em <http://www.cedes.unicamp.br> 
A poesia do corpo: a defesa de uma moral austera

and conflicts" that may have marked his future intellectual production. It explores more specifically how the theme of the "lowering of the moral level" in Brazil emerges in Fernando de Azevedo and other intellectuals of his time, such as Olavo Bilac, Coelho Neto, Euclides da Cunha and Monteiro Lobato.

Key words: Fernando de Azevedo. Brazilian social thought. Public education. Moral education and organicism. Physical education.

A o publicar A poesia do corpo como tese de concurso ao Ginásio Mineiro, Fernando de Azevedo dedicou-a ao então ex-presidente do Estado de Minas Gerais, Júlio Bueno Brandão, e aos deputados federais Jayme Gomes e Bressane de Azevedo, afirmando fazêlo "pelas relaçôes de profunda amizade e laços de parentesco que os ligavam" (Azevedo, 1915, p. 1). Dedicou também ao presidente em exercício do Estado de Minas Gerais, Delfim Moreira; dedicou ainda "à Conspícua Congregação do Ginásio Mineiro, como tributo de homenagem e respeito" (idem, ibid., p. 2).

Não sabemos se esse tipo de dedicatória dirigida a pessoas pertencentes ao poder político do período era usual nas teses de concurso do Ginásio Mineiro. O que queremos destacar é que a dedicatória de sua tese ao ex-presidente do Estado de Minas Gerais, Júlio Bueno Brandão, e ao presidente em exercício Delfim Moreira, que deram a Fernando de Azevedo um certo apoio político, pode ser vista, por um lado, como uma forma de reconhecimento e de amizade e, de outro, como um pedido de continuidade desse apoio durante o concurso; com relação aos deputados federais, entendemos da mesma forma.

Com relação às posições que Fernando de Azevedo defendia nos seus estudos autobiográficos, no sentido de não procurar achegar-se aos detentores do poder político do período em Minas Gerais, nessa dedicatória é possível observar como o "purismo" é deixado de lado. Mesmo que sua intenção mais clara fosse expressar amizade e o reconhecimento pelo apoio já recebido, o fato revela que ele conseguia ter acesso, dentro de determinados limites, aos poderosos do Partido Republicano Mineiro.

A tese de concurso A poesia do corpo, apresentada sob a forma de livro, divide-se em três partes: a primeira vem a ser um estudo da ques- 
tão da educação física, a segunda apresenta as escolas e os métodos mais significativos de educação física e a terceira é um estudo sobre a importância do problema da educação física no Brasil, com o levantamento de propostas.

No início do prefácio do trabalho, Fernando de Azevedo, ao se referir à educação, à tarefa educativa, o faz utilizando a terminologia "missão educativa". Considera, com muita ênfase, ser essa missão educativa uma tarefa admirável e nobre, e portanto complexa, reconhecendo também que bem realizá-la sempre foi uma tarefa difícil. Alerta, entretanto, definindo-a como "mais difícil do que nunca" no contexto de 1915, afirmando que "Os Pestalozzi e os Girard contemporâneos lutam por certo com maiores dificuldades peculiares à quadra que atravessam" (Azevedo, 1915, p. 11; Prefácio). ${ }^{1}$

Embora não explicite no texto, acreditamos que Fernando de Azevedo, ao destacar ser a missão educativa, em 1915, uma tarefa mais difícil do que nunca, está reconhecendo e indicando que pensar e realizar essa tarefa, naquela conjuntura, reservava maiores dificuldades, em decorrência das "peculiaridades da quadra", isto é, pela realidade da Primeira Guerra Mundial.

A partir disso, podemos entender estar o jovem Fernando de Azevedo, ao viver sua experiência como professor substituto de latim e psicologia no Ginásio Mineiro, que lhe abriu um campo de estudos também ao nível do pedagógico, demonstrando o seu reconhecimento com relação ao trabalho de renovação feito pelos educadores dos séculos XVIII e XIX, que implicou a difusão de procedimentos científicos importantes para o campo educacional, entre os quais se insere a questão da educação física.

Entretanto, ao mesmo tempo em que reconhecia o trabalho desses educadores dos séculos XVIII e XIX, percebemos que ele, ao escrever seu primeiro trabalho intelectual, contextualiza sua fala, estando preocupado com os "Pestalozzi" e os "Girard" contemporâneos. Estes deveriam pensar e realizar a "missão educativa", tendo em vista as peculiaridades do século XX, enfrentando também as "dificuldades da quadra que atravessávamos”, nas décadas iniciais do século XX.

Além da questão crucial da Primeira Guerra Mundial, Fernando de Azevedo procura em sentido mais amplo indicar que, apesar de incorporar os avanços importantes da pedagogia dos séculos XVIII e XIX 
A poesia do corpo: a defesa de uma moral austera

e das contribuições feitas com relação à questão da educação física, a pedagogia do século XX transformou-se, estendendo-se essas transformaçôes que sofreu aos diferentes domínios do campo educacional.

Parece-nos querer ele dizer que os educadores do século XX não poderiam "confundir os tempos". Refere-se, então, já no Prefácio, àquilo que vai afirmar no desenvolvimento desse seu trabalho: "Confundimos as idéias, porque confundimos os tempos". Para ele, as preocupaçôes que absorviam o espírito dos educadores no século XX não podiam ser as mesmas que empolgaram os educadores dos séculos XVIII e XIX.

Azevedo já tinha, em 1915, um significativo conhecimento da literatura que vinha sendo produzida, nos movimentos pedagógicos do início do século XX, por educadores de outros países. Reunia, então, informações de como as circunstâncias que marcaram os três primeiros lustros do século estavam provocando, nos educadores estrangeiros e também brasileiros que pensavam a questão educacional, a necessidade de uma revisão da função social da escola, de suas técnicas e de sua ação social; a Primeira Guerra Mundial influíra em muitos países, repercutindo na teoria educacional e levando à produção de novos estudos no campo educacional, assim como uma "nova fé" na escola.

Consideramos que, ao fazer referência às peculiaridades difíceis do século XX e, principalmente, de 1915, que tornava a "missão educativa", além de "admirável, nobre, complexa" e "mais difícil do que nunca", Fernando de Azevedo estava destacando, em termos amplos, tanto o quadro internacional como o nacional. Sua preocupação mais direta, ao indicar essas peculiaridades, era, no entanto, interpretar a nossa realidade endógena, isto é, a tarefa da missão educativa na sociedade brasileira, em 1915, procurando destacar o papel da educação física nesse processo. Escreve, indicando, já no Prefácio, como via a conjuntura daquela época:

Não deixamos de reconhecê-lo. O nível moral baixou, desfibrou-se o organismo, à medida que as idéias também desceram. E, a bem dizer, parece que nem idéias há numa grande parte dos espíritos, há sensaçóes e um sentimentalismo doentio, quando não campeia a moral epicuréia - a moral do prazer, e já os sentimentos e as emoçóes ameaçam o posto às idéias, esterilizam o espírito, chegam a poluir o pensamento, e quase exclusivamente dirigem o homem, reduzido pela escola positivo-criminalista a um organismo galvânico, diversamente carregado pelo meio social e pela força do atavismo. (Azevedo, 1915, p. 11) 
Embora, em linhas gerais, na citação que apresentamos, Fernando de Azevedo estivesse também se referindo às peculiaridades que o mundo estava atravessando, julgamos que seu interesse fundamental era o de indicar a sua maneira de ver o que estava acontecendo com relação à sociedade brasileira, na qual reconhecia a ausência de um "ideal" condutor.

Constatava que as "idéias desceram" e, por conseqüência, "baixou o nível moral". Em conseqüência disso, o "organismo" (empregado no sentido de sociedade, por meio da analogia organicista) encontravase "desfibrado".

Existia, ainda, nessa conjuntura, na sociedade brasileira, uma concepção de homem fundamentada na "escola positivo-criminalista". $\mathrm{O}$ autor reconhecia a importância que a "escola positivo-criminalista" tinha, em 1915, nas análises sobre a sociedade brasileira. Ao mesmo tempo em que ele reconhecia sua influência, preocupava-se com as explicaçōes dessa escola, criticando a concepção de homem, na qual ela se fundamentava, que o reduzia "a um organismo galvânico, diversamente carregado pelo meio social e pela força do atavismo" (Azevedo, 1915, p. 11).

Essa sua preocupação, que para nós revela uma crítica à forma pela qual essa escola "reduzia" o homem, parece-nos importante, não só pelo fato de ter sido feita em 1915, mas também por ter vindo de um estudante de direito, pois acreditamos que as posições formuladas por essa escola deveriam, naquela conjuntura, encontrar grande receptividade nos cursos de direito do país.

Julgamos que o acesso de Fernando de Azevedo ao estudo dessa escola foi possível em parte pelas suas atividades como professor de psicologia, mas, especificamente, esta fundamentação teórica deve ter sido assimilada pelo autor enquanto aluno da Faculdade de Direito, onde, com quase toda a certeza, no direito penal deve ter estudado a importância da "Escola Positiva", fundada pelo médico-psiquiatra Cesare Lombroso. $^{3}$

Considerava ele, conforme indicamos anteriormente, que dominava no país, em 1915, uma "moral do prazer". Em razão do predomínio dessa moral, acreditando que as ações dos indivíduos eram "aquilatadas e olhadas", na medida em que, em si, produziam ou originavam prazer, preocupava-o o predomínio de uma moral que levava, em geral, as pessoas a não desenvolverem ações que exigissem "trabalho e sacrifício". ${ }^{4}$ 
A poesia do corpo: a defesa de uma moral austera

Diagnosticava essas peculiaridades da conjuntura de 1915, considerando que os educadores dessa época deveriam reconhecê-las e atuar sobre elas, transformando-as.

Quanto à educação corporal, entendia que tais peculiaridades levavam como decorrência natural a um "menoscabo pela educação física no país". Reconhecendo essa realidade, indicava sobre a "vida nacional" o seguinte "círculo vicioso": "desprezamos a cultura do corpo, porque somos fracos; somos fracos porque desprezamos a cultura do corpo" (idem, ibid., p. 12).

Fracos e desfibrados encontravam-se, no seu entender, o organismo social e os organismos individuais. Embora tivesse certeza de que, para a transformação dessa aporia, medidas amplas deveriam ser tomadas, via como contribuição sua para a saída desse quadro e do "círculo vicioso" por ele indicado, o qual nos mantinha fracos, um processo de "cultura do corpo".

Embora o texto não mencione explicitamente a expressão "crise", julgamos que Fernando de Azevedo via o Brasil, na conjuntura de 1915, como que atravessando uma situação cultural e socioeducativa compatível com as noçôes que esse vocábulo resume.

Antes de analisarmos a postura de Fernando de Azevedo, com relação ao rebaixamento "do nível moral" (1915, Prefácio), nos seus aspectos teóricos mais amplos, verificando, ao longo do texto de $A$ poesia do corpo, se ele procura fazer, de uma forma mais sistemática, uma crítica à moral que considerava ser dominante no país na época, consideramos importante lembrar, inicialmente, que esse tipo de formulação, na direção do "rebaixamento do nível moral", tem raízes na sua trajetória anterior a 1915.

Destacamos - e é importante lembrá-lo de uma forma sintética que Fernando de Azevedo foi socializado na família, assim como nos colégios por que passou, sob os cuidados dos jesuítas, sob a égide de uma "formação moral austera", fundamentada na valorização de "ações que exigem trabalho e sacrifício".

Com essa formação aprendeu a valorizar o "domínio de si mesmo", por meio do "esforço" e da "tenacidade", e a respeitar a disciplina e a hierarquia, desde que compreendidas nos seus objetivos.

Aprendeu, também, com essa "moral austera", a "valorizar o esforço" no sentido da "educação da vontade" e dos "instintos", visando 
alcançar o aperfeiçoamento intelectual, moral e espiritual, na busca, diríamos nós, de uma "segunda natureza", que veio a ser adquirida por meio da educação familiar, continuada pela "disciplina rigorosa dos jesuítas".

Aprendeu, ainda, em sua trajetória escolar, a valorizar a razão na educação. Esta deveria levar o indivíduo ao exercício da razão, pelo caminho da ética.

As formulações no sentido do "rebaixamento do nível moral", explícitas em $A$ poesia do corpo, estiveram presentes na literatura do período e foram muito comuns nas crônicas publicadas na imprensa da época.

Acreditamos que alguns intelectuais integrantes da "geração prémodernista de 1870 " estão presentes já no seu primeiro trabalho intelectual e que tiveram importante papel na sua formação intelectual (Sevcenko, 1983; Cap. II, parte I).

Não só no contexto da Primeira Guerra, mas já no início da República, muitos intelectuais da "geração modernista de 1870", que lutaram pela república, na medida em que acreditavam que esta levaria à "democratização do regime", fizeram a crítica desse regime, abordando a questão do "rebaixamento do nível moral".

Alguns desses intelectuais mencionados construíram, por meio do seu "nacionalismo intelectual", interpretações importantes para esse período sobre o Brasil, em que analisam por que acreditaram na República e como se tornaram, conforme expressão lembrada por Nicolau Sevcenko, "paladinos malogrados", que se decepcionaram com o novo regime, sentindo-se, na qualidade de "homens de talento", sem espaço nesse mesmo regime (ibid., p. 86-93; parte II).

Entre os desiludidos, Sevcenko destaca Euclides da Cunha, cuja influência sobre Fernando de Azevedo consideramos muito importante, no início de sua produção cultural. Em A poesia do corpo, Euclides da Cunha aparece como um autor importante a quem Fernando de Azevedo recorre por diversas vezes para pensar e interpretar o Brasil.

O que pretendemos destacar, em linhas gerais, é que Fernando de Azevedo recebeu influência desses "paladinos malogrados", dentre os quais procuraremos indicar, numa perspectiva ainda muito inicial, aqueles que conseguimos identificar como importantes para sua formação. Sua trajetória até 1915 mostra que, ao iniciar a explicitação de suas posições políticas, apoiou a candidatura de Rui Barbosa. 
A poesia do corpo: a defesa de uma moral austera

Indica Sevcenko, no mesmo trabalho a que já fizemos referência, alguns intelectuais dessa geração modernista de 1870 que passaram a rever a história do seu país e a construir "interpretaçôes sobre o Brasil", procurando exercer a concepção de intelectual que defendiam, que consistia em ser, ao mesmo tempo, "homens de pensamento e de ação".

A crítica relacionada com o "rebaixamento do nível moral", feita por Fernando de Azevedo no Prefácio de A poesia do corpo, foi uma constante em intelectuais como Rui Barbosa, Olavo Bilac, Coelho Neto e Monteiro Lobato, que protestavam nos jornais contra a "falta de espírito público dos governantes". Denunciavam eles o "favoritismo político" nos empregos e acesso a cargos, a falta de "ideais éticos", "as cavaçôes", o "arreveso", a falta de "solidariedade social" e de "conduta moral", assim como a perda da "noção de sacrifício", enfim, o individualismo exagerado que passou a existir no "novo regime".

Esses autores, segundo Sevcenko, apontavam em sua crítica a vigência de "velhos costumes políticos", por meio do "coronelismo", que levava ao nu exercício da "representatividade" que deveria ser própria de um regime democrático, e o fato de que o Estado estava "reduzido ao servilismo político". Daí decorre que

impressão que os críticos da cultura transmitem pela imprensa, a respeito do período, era de se estar atravessando uma profunda crise intelectual e moral, marcada pela mais atroz decadência cultural. Em tom acrimonioso e pessimista, falava-se de "vazio de idéias" e "fim de uma tradição". (Sevcenko, 1983, p. 95)

Esse tipo de crítica que reconhecia a "queda do nível moral", já existente antes de 1915, vai se acentuar no contexto da Primeira Guerra, que favorecia o surgimento de manifestaçōes nacionalistas.

Temos de compreender, portanto, as posições de Fernando de Azevedo, no Prefácio e ao longo do livro $A$ poesia do corpo, como inseridas numa conjuntura mais ampla. Estamos procurando entendê-las no contexto das propostas nacionalistas que ocorreram nesse período.

Parece-nos que foi essa conjuntura, onde se destacava a concepção de que somente o país mais forte sobreviveria, que influenciou o pensamento de Fernando de Azevedo nesse seu primeiro trabalho e foi, em grande parte, resultado da Primeira Guerra; em A poesia do corpo, já no Prefácio, ele aponta que uma das estratégias para que o Brasil pu- 
desse se tornar uma nação forte seria por meio do desenvolvimento da educação física no país.

Ele trabalhará com o conceito de nacionalidade e defenderá a idéia de "regeneração social do país", tendo como estratégia a educação física. Pautava-se ele pela idéia da defesa da "regeneração social" em nível nacional, vendo na escola um espaço relevante para a obra de regeneração da sociedade, sendo que no campo educacional a educação física desempenhava um papel muito importante.

Em 1915, quando escreveu $A$ poesia do corpo, era muito comum a idéia de que o povo brasileiro vivia uma situação de "nacionalidade depauperada".

Silvia Levi Moreira mostra que, em geral, nesse período, o jornal $O$ Estado de S. Paulo publicava artigos propugnando o combate à "letargia" e ao "marasmo" e defendendo a "ação como a estratégia para a salvação do regime". Entre os assuntos mais discutidos nesses artigos se destacavam: educação e escotismo, o voto secreto e obrigatório e o serviço militar obrigatório.

A escolarização, conforme reconhece essa autora, foi, "entre os meios escolhidos" para o "reerguimento nacional", o instrumento tido como "o mais adequado para acelerar o processo histórico", o "recurso" considerado privilegiado para "remediar os males que afetavam o regime republicano". ${ }^{6}$

Em 1915, ao pensamento de que o povo brasileiro vivia uma situação de "nacionalidade depauperada", agregava-se a noção de que o "organismo estava desfibrado".

Esse tipo de discurso, relacionado com o "rebaixamento do nível moral", está presente em interpretaçôes feitas sobre o Brasil, que julgamos foram importantes para Fernando de Azevedo quando escreveu $A$ poesia do corpo e que localizamos principalmente em Olavo Bilac, Coelho Neto, Euclides da Cunha e Monteiro Lobato, apesar de eventuais divergências teóricas que apresentem relativamente ao tema.

A seu modo, todos esses autores também criticaram a "moral do prazer", que julgavam dominante na época, e viram a necessidade de serem encontradas alternativas para o país, que consideravam estar atravessando uma séria crise. E, ainda, à sua maneira, criticaram a "moleza", a "indolência", a "ociosidade" e caminharam mais na direção de uma "moral austera". 
A poesia do corpo: a defesa de uma moral austera

\section{Olavo Bilac}

Sem pretendermos fazer um estudo aprofundado, mas apenas levantar neste trabalho algumas hipóteses com relação a Olavo Bilac, acreditamos que esse poeta - o paladino da campanha nacionalista teve grande influência na formação de Fernando de Azevedo.

A emergência das propostas nacionalistas certamente atuou sobre as posições assumidas por Fernando de Azevedo por ocasião da elaboração do texto de $A$ poesia do corpo.

A idéia do "rebaixamento do nível moral" pode ser observada no texto da conferência de Bilac feita aos estudantes da Faculdade de Direito de São Paulo em 9 de outubro de 1915, sob o título "Em marcha" (Bilac, 1924, p. 116-122), e acreditamos que esta ecoou sobre o jovem Fernando, então estudante de direito. Bilac reconhecia, já no início de sua conferência, a gravidade na situação moral do país.

Preocupava-o o espetáculo apresentado pelas "classes cultas", em cujo seio grassava o egoísmo, cada qual por si buscando o gozo, a prosperidade, o brilho, o rápido enriquecimento "seja como for, através de todas as traições, por cima de todos os escrúpulos", enquanto os políticos profissionais, após se locupletarem, contentavam-se com a passiva e ridícula vaidade do mando fictício, assim como o que acontecia no nível das "camadas populares", que, a seu ver, eram "mantidas na mais bruta ignorância", mostrando "só inércia, apatia, superstição, absoluta privação da consciência". Preocupava-se ele com a realidade dos sertôes, onde, na sua visão, os "homens não eram brasileiros", "nem verdadeiros homens". Preocupava-o estar o país "povoado de analfabetos", assim como a realidade da "instrução primária" e da "instrução profissional". Escreve Bilac a respeito disso:

Esse é o espetáculo que nos deparam as classes cultas. As outras, as mais humildes camadas populares, mantidas na maior bruta ignorância, mostram só inércia, apatia, superstição, absoluta privação da consciência. Nos rudes sertôes, os homens não são brasileiros, nem ao menos são verdadeiros homens: são viventes sem alma criadora e livre, como as feras, como os insetos, como as árvores. A maior extensão do território está povoada de analfabetos; a instrução primária, entregue ao poder dos governos locais, é, muitas vezes, apenas, uma das rodas da engrenagem eleitoral de campanário, um dos instrumentos de maroteira política. Quanto à instrução profissional, - essa, na maior parte dos Estados da União, é um mito, uma fábula, uma ficção. 
Lembrai-vos que, se a escravidão foi um crime hediondo, não foi menos estúpido o crime praticado pela imprevidência e pela incapacidade dos legisladores, dando aos escravizados apenas a liberdade, sem lhes dar o ensino, o carinho, o amparo, a organização do trabalho, a habilitação material e moral para o exercício da dignidade cívica (...). (Idem, ibid., p. 118-119).

O que mais preocupava Bilac, que via o tema da educação da juventude como prioritário para a regeneração do país, era a questão da necessidade da "definitiva constituição da nacionalidade", e ele deplorava, então, o fato de não se estar fazendo nada para isso.

Reconhecia, em 1908, a existência de um "rebate ansioso e febril" na imprensa e na tribuna, o qual significou um "toque de alarma a todas as energias adormecidas". Referia-se à lei do sorteio militar, que, para ele, "apontou a esperança e entreluziu uma promessa de salvação". Essa lei, para Bilac, não significava a providência completa do serviço militar obrigatório, mas representava um ensaio salutar, isto é, o primeiro passo "para a convalescença e para a cura". O serviço militar generalizado era o "remédio" para o "definhamento" que se observava no país, o "triunfo completo da democracia", pois "nivelava as classes", significava a escola da ordem, da disciplina, da coesão, o laboratório da dignidade e do patriotismo.

Por meio de uma série de medidas, a caserna, segundo Bilac, deveria atuar sobre os "rebotalhos da sociedade", regenerando-os em todos os níveis. Era assim que ele se referia à população mais pobre, concentrada nas cidades. ${ }^{7}$

Eis como Bilac se expressa sobre isso:

Que se tem feito, que se está fazendo, para a definitiva constituição da nacionalidade? Nada. Os imigrantes europeus mantêm aqui a sua língua e os seus costumes. Outros idiomas e outras tradições deitam raízes, fixam-se na terra, viçam, prosperam. E a nossa língua fenece, o nosso passado apaga-se.

Há sete anos, houve um rebate ansioso e febril. Na tribuna e na imprensa, vibrou um alto chamamento, um toque de alarma a todas as energias adormecidas. E uma lei apontou à nossa esperança o entreluzir de uma promessa de salvação: a lei do sorteio militar, se não a providência completa do serviço militar obrigatório, ao menos um ensaio salutar, o primeiro passo para a convalescença e para a cura. Então, como ainda hoje, eu considerava que era esse o único providencial remédio para o nosso definhamento. Nunca fui, não sou, nem serei um militarista. E não te- 
A poesia do corpo: a defesa de uma moral austera

nho medo de militarismo político. O melhor meio para combater a possível supremacia da casta militar é justamente a militarização de todos os civis: a estatocracia é impossível, quando todos os cidadãos são soldados. Que é o serviço militar generalizado? É o triunfo completo da democracia; o nivelamento das classes; a Escola da ordem, da disciplina, da coesão; o laboratório da dignidade própria e do patriotismo. É a instrução primária, obrigatória; é a educação cívica obrigatória, a regeneração muscular e física obrigatória. As cidades estão cheias de ociosos descalços, maltrapilhos, inimigos da carta do "Abc" e do banho - animais brutos, que de homens têm apenas a aparência e a maldade. Para esses rebotalhos da sociedade a caserna seria a salvação. A caserna é um filtro admirável, em que os homens se depuram e apuram: dela sairiam conscientes, dignos brasileiros, esses infelizes sem consciência, sem dignidade, sem pátria, que constituem a massa amorfa e triste de nossa multidão... Mas nada se fez... O mesmo homem, o mesmo marechal, que, quando ministro da Guerra, promoveu esse movimento salutar em favor da nacionalidade, no dia em que subiu ao supremo poder foi o primeiro a esquecer a sua criação, deixando-a morta no berço. E hoje, depois de um quatriênio de lutas estéreis e de politicagem sem moral, o problema terrível permanece sem solução: uma terra opulenta em que muita gente morre de fome, um país sem nacionalidade, uma pátria em que não se conhece o patriotismo (Bilac, 1924, p. 119-121; grifos nossos).

No final da conferência, Bilac faz um apelo para que os estudantes assumam esse ideal de constituição de nossa nacionalidade, unindo-se os estudantes da Faculdade de Direito de São Paulo a todos os moços e estudantes do Brasil, de tal forma que, "num exército admirável", fossem "os escoteiros de nossa fé".

Um outro texto de Bilac, que coloca essa idéia do "rebaixamento do nível moral" e que tem como título "O cancro", constitui um discurso que fez aos estudantes da Faculdade de Medicina de São Paulo, em 14 de outubro de 1915 (idem, ibid., p. 123-127), ${ }^{8}$ no qual volta a falar sobre a profunda crise que afeta o país. Utiliza-se, na sua interpretação, de forma muito acentuada, da "fantasmagoria orgânica", especialmente por meio da metáfora do câncer. Escreve Bilac:

Falo-vos como poeta, e como velho e impenitente estudante. Como poetas, e como futuros médicos, meus jovens irmãos, amai o Brasil, e dai assistência à pátria enferma!

Conheceis, ou conhecereis, entre os casos clínicos, que vistes ou vereis, uma das mais terríveis desgraças do organismo humano, a mais cruel, talvez, de 
todas as misérias físicas. Um leve endurecimento, a princípio, e uma ligeira corrosão na pele ou na mucosa; em seguida, o alargamento e a penetração do núcleo destruidor; e o tumor lançando raízes envenenadoras, polvo hediondo, dilatando e aferrando os seus tentáculos vorazes, mordendo e triturando os tegumentos, roendo e comendo os tecidos, e a marcha fatal e implacável da ruína, desfazendo as carnes em sânie; e o mal sem cura infiltrando-se em todo o corpo; e o vírus letal intoxicando todo o sangue, mirrando e extinguindo a força; e, enfim, a caquexia, o marasmo, a agonia, e a morte. É o cancro. (Bilac, 1924, p. 124-125)

Continua Bilac, apontando que o câncer estava presente também no organismo social, no corpo brasileiro:

Ora, este flagelo do organismo físico existe também no organismo social. As sociedades, como os indivíduos, são às vezes devastadas por essa mesma doença, de sintomas idênticos, de marcha igualmente assustadora, de conseqüências igualmente funestas. É a mesma voracidade, o mesmo enraizamento, a mesma infecção, a mesma discracia, o mesmo depauperamento, a mesma destruição. Este carcinoma da estrutura moral é a indiferença; e os seus tentáculos ferozes insinuando-se, verrumando, terebrando, infeccionando, ressumando uma baba viscosa e mortífera, desagregando e devorando a presa, - são a fraqueza da alma, o desânimo, o egoísmo, a autolatria, o amor exagerado do luxo e do dinheiro, a falta de patriotismo, e o aniquilamento do caráter próprio pelo desdém dos interesses sagrados da comunhão.

Alguns sintomas deste morbo ignóbil já se manifestam em várias zonas do grande corpo brasileiro. (Idem, ibid., p. 127-128; grifos nossos) ${ }^{9}$

Destacava ele, ainda, no texto, que, embora até então não tivesse sido descoberto um remédio para o carcinoma físico, ele reconhecia existir remédio para o carcinoma moral e social, que ele julgava ser a doença do período. O antídoto para combater esse mal deveria ser "profilático, regenerador e curativo". Para a mudança desse quadro, deveriam ser desenvolvidas: a crença individual, o entusiasmo pessoal, a coragem cívica. Esta última parecia a Bilac a "salvaguarda da coletividade, a manutenção e a grandeza da Pátria”.

Era preciso debelar a diatese que ameaçava a nacionalidade brasileira. Conclamava os estudantes da Faculdade de Medicina para que contribuíssem, no nível da ciência médica, para que surgisse um salvador que conseguisse combater e prevenir a diatese cancerosa. Conclamava-os, no entanto, para o mais grave, isto é, para debelarem, também como salva- 
A poesia do corpo: a defesa de uma moral austera

dores, naquele momento, a diatese que ameaçava a nacionalidade brasileira, para que, além de médicos para os corpos, viessem a ser médicos também para as almas, isto é, para a "grande alma do Brasil".

Também destacava a fealdade das doenças que acometiam o país na época - a desnacionalização da gente brasileira, a tibieza dos governos, a perda de entusiasmo e a falta de coragem e de fé - no discurso que fez no banquete oferecido pelo Exército, no edifício do Clube Militar, no Rio de Janeiro, em 6 de novembro de 1915. Tal discurso foi publicado com o título: "Ao exército nacional" (idem, ibid., p. 129).

Para Bilac, as classes cultas, portadoras de instrução, pensamento e consciência, é que deveriam atuar no sentido de contornar a crise existente. As transformações do quadro por ele percebido deveriam ser feitas dentro do regime republicano. E era preciso que, por meio da uniāo das classes cultas, se encontrasse uma terapêutica para a doença nacional, cujos remédios entendia ele serem o tempo, a tenacidade e o devotamento.

A questão da educação do corpo, entendida como moralização do corpo, já aparecia em Bilac por intermédio do serviço militar obrigatório, levantando os vários aspectos que ele percebia de filtragem, de aprimoramento, a questão referente à regeneração física e muscular daqueles que denominava de rebotalhos da sociedade.

A relação entre educação do corpo e processo de trabalho parecenos estar sendo discutida no período. Isso não quer dizer que esta colocação fosse no sentido da defesa somente da escola como locus da produção da educação física, na qualidade de disciplina de ensino.

Acreditamos que, no contexto da regeneração, colocou-se, mesmo que tenha sido de forma difusa, a questão do corpo, assim como as questôes da beleza e da fealdade. Enfim, de corpos que deveriam ser civilizados e que eram fonte de preocupação na temática mais geral da constituição da nacionalidade.

Bilac defendia uma nova política para o país que, tal como deparamos em Fernando de Azevedo, deveria ser "fillha da moral e da razão". ${ }^{10}$

\section{Coelho Neto}

Como já indicamos anteriormente, acreditamos existir também a presença de Coelho Neto nesse início da produção cultural de Fernando de Azevedo, tendo sido ele um intelectual importante para aquela geração. 
No caso de Coelho Neto, julgamos ${ }^{11}$ ter isso ocorrido por ser, além do fundador da "Liga de Defesa Estética", um "incentivador dos esportes", e isso podemos observar pelas campanhas que neste sentido realizou. Nataniel Dantas (1984, p. 28) ${ }^{12}$ escreve sobre Coelho Neto:

A divisa mens sana in corpore sano foi por ele seguida à risca. Num tempo em que não se praticavam esportes, a vida ao ar livre, em que banho de mar só a conselho médico e, assim mesmo, acolitado por banhistas profissionais do Boqueirão, o escritor fazia pelos jornais e em conferência a apologia dos esportes, da vida ao ar livre, comum entre os gregos. Foi um dos fundadores do Fluminense e deu ao clube das Laranjeiras dois craques, os filhos Mano e Preguinho. O primeiro morreria em conseqüência de um acidente numa partida de futebol e seria a razão de um livro comovente, Mano. Preguinho passou à história do atletismo como um dos mais perfeitos, nunca superado pelos pelés da vida.

Propõe, ainda, esse autor:

(...) se os reservistas têm em Olavo Bilac o patrono pela campanha em favor do serviço militar obrigatório, por que Coelho Neto não pode e nem deve ser dos nossos desportos? Que se convoquem os advogados, os advogados-do-diabo e se faça um levantamento de sua ação, de suas campanhas, pois agiu sozinho, sem patrocínio, num tempo em que não havia MEC e nem Olimpíadas, e a educação andava entregue às responsabilidades do Ministério da Justiça! Uma medalha, uma prova, uma coroa de louros, uma taça, um estádio Coelho Neto, que o próprio Fluminense esqueceu de lhe dar o nome. Por que não? (Dantas, 1984, p. 29)

Julgamos, como mostra Nicolau Sevcenko no livro a que estamos fazendo referência, ter sido Coelho Neto um intelectual importante no contexto da "regeneração", isto é, do processo que se iniciou na cidade do Rio de Janeiro.

Esse autor lembra, ao estudar o processo de regeneração, "o pioneirismo de Luiz Edmundo, à frente da sua Liga Contra o Feio, já em 1908, e Coelho Neto liderando a Liga de Defesa Estética, em 1915" (Sevcenko, 1983, p. 37). ${ }^{13}$

Consideramos que a literatura produzida no contexto da "regeneração" por muitos autores devia estar colocando, embora de forma muito difusa, a questão da educação física como caminho para a "regeneração física e social". 
A poesia do corpo: a defesa de uma moral austera

Em período posterior ao coberto por essa pesquisa, Coelho Neto iria se corresponder com Fernando de Azevedo, lutando para encaminhálo à Academia Brasileira de Letras. ${ }^{14}$ Atesta, a esse respeito, Fernando de Azevedo em suas memórias:

Quem teve a primeira lembrança de me levar para a Academia Brasileira foi Coelho Neto, com quem já me correspondia e que veio a São Paulo, em 1923, para conversar comigo sobre o assunto. Entendia ele que devia reunir em volume os estudos que vinha publicando no Correio Paulistano, sobre a antigüidade latina, para me ir dispondo a apresentarme candidato a uma das vagas que aparecessem na Academia Brasileira. Foi ele quem sugeriu o título para esse livro de ensaios: No tempo de Petrônio. Aceitei a sugestão e Coelho Neto ficou de procurar, no Rio, o editor e mandou-me a minuta da escritura. Mas acontece que a Editora Livraria Castilho, que se propunha a publicar o livro, requereu falência. Pedi então a Coelho Neto não recorresse a outra editora para não se dar o que acontecera com a Livraria Castilho (...). Procurei então a Livraria da Globo, dos Irmãos Marrano, à Rua Líbero Badaró, que se propôs a lançar, como lançou, a primeira edição de No tempo de Petrônio, dedicada a Coelho Neto. (Azevedo, 1971, p. 201)

Continua Fernando de Azevedo:

O que desejava Coelho Neto, quando me sugeriu reunir esses ensaios e publicá-los, era facilitar o lançamento de minha candidatura à Academia Brasileira. Tinha eu, então, apenas um livro editado pelos Irmãos Weissflog Incorp., Da educação física - o que ela é, o que tem sido e o que deveria ser, que alcançava grande sucesso de livraria e fora largamente comentado em jornais e revistas. Se a esse volume, com ilustrações de Thorwald Rasmussen, se acrescentassem uma conferência sobre atlética e um ensaio sobre "A evolução dos esportes no Brasil", publicado em $O$ Estado de S. Paulo, na edição comemorativa da Independência do Brasil, era a isso que se reduzia toda minha obra publicada em livro e opúsculos. É certo que, a essa altura (1922), já começava a escrever os rodapés de crítica literária no $O$ Estado de S. Paulo, para onde me transferira do Correio Paulistano, em que iniciara em São Paulo minha carreira jornalística. Mas a publicação em volume, de meus estudos sobre a antigüidade romana a que Coelho Neto dava uma tenção especial, só podia reforçar as bases de sustentação de minha candidatura à Academia Brasileira. Daí o interesse do eminente escritor por esse novo livro, para o qual me sugerira o próprio título e procurou editor, no Rio de Janeiro.

Foi, porém, mais longe Coelho Neto no empenho, com que tanto me cativou, de levar-me à Academia. Como, por várias vezes lhe havia decla- 
rado abrindo-me com ele, que não gostaria de disputar uma cadeira, por entender que honrarias se concedem e não se disputam, propôs ele importante modificação nos estatutos acadêmicos. A saber: verificada uma vaga, em vez de abrirem logo inscriçōes para apresentação de candidatos, ter-se-ia de proceder à eleição, de um nome indicado por dez acadêmicos. Se o nome apontado pelos dez conseguisse os votos necessários para atingir a maioria absoluta, seria considerado eleito e o Presidente da Academia se encarregaria de participar sua eleição ao escritor ou poeta escolhido sem se ter apresentado candidato. Somente no caso de não se conseguir a maioria ao nome apontado para a Cadeira, é que se abririam as inscrições para apresentação de candidatos. Essa proposição, recusada in limite, na ocasião, foi lembrada, restabelecida e aprovada para a eleição do Presidente Vargas e, pouco tempo depois, rejeitada, voltando-se, por essa forma, ao antigo e exclusivo sistema para o provimento de vagas na Academia Brasileira. (1971, p. 201-202; grifos nossos)

Apesar de explicitar em suas memórias que no nível pessoal não se interessava pela disputa de honrarias, ${ }^{15}$ esse fato indica como, já muito cedo (1923), Azevedo recebia o apoio de um intelectual dos mais "eminentes" do país e como já "namorava" um lugar na Academia, colocandose como um "homem de letras" e procurando alcançar um espaço muito valorizado culturalmente nesse período.

\section{Euclides da Cunha}

Consideramos que, de todos os autores indicados, foi Euclides da Cunha o que mais influíra em Fernando de Azevedo no início de sua produção cultural, pois a obra euclidiana foi de grande influência não só para Azevedo, mas, como acreditamos, para toda sua geração.

Apesar de pertencerem a gerações diferentes, sendo Euclides da Cunha 28 anos mais velho que Fernando de Azevedo, esse autor aparece de forma muito nítida no início da produção cultural de Fernando de Azevedo e já de forma significativa no seu primeiro trabalho. ${ }^{16}$

É possível, e mesmo necessário, lembrar o "patrimônio cultural" desse período em que Fernando de Azevedo viveu. Nele, Euclides da Cunha detinha uma influência segura... ${ }^{17}$

Sobre ele, Azevedo escreveu o texto intitulado "O homem Euclides da Cunha", publicado no seu livro $\mathrm{Na}$ batalha do humanismo (São Paulo: Melhoramentos, 1952, p. 171-195). O texto em questão 
A poesia do corpo: a defesa de uma moral austera

foi escrito para uma conferência, proferida em 30 de agosto de 1951, no salão nobre da Faculdade de Filosofia, Ciências e Letras da Universidade de São Paulo.

Ao iniciá-lo, indicando ter sido feita essa conferência no mês dedicado "às solenes comemoraçōes da vida e obra do escritor singular", lembra Fernando de Azevedo a figura de um grande amigo, intelectual muito respeitado por ele. Refere-se a Francisco Venâncio Filho, afirmando ter sido Euclides da Cunha um de seus maiores cultos. ${ }^{18}$

Até o período em que escreveu o texto de sua conferência, considerava ser o estudo do intelectual e amigo o melhor trabalho escrito sobre Euclides da Cunha e reconhecia, concordando com ele, ter sido Euclides da Cunha o "mais brasileiro de todos os escritores". ${ }^{19}$

Fernando de Azevedo situa o seu próprio texto, de 1952, como tendo sido o atendimento de um último pedido do amigo feito em São Paulo, em 9 de agosto de 1946, pouco tempo antes de morrer, reiterando-lhe que fizesse uma conferência durante a comemoração da Semana Euclidiana, em São José do Rio Pardo. Essa conferência, proferida na Universidade de São Paulo, foi de certa forma uma homenagem de Fernando de Azevedo ao amigo Venâncio Filho.

Admirava em Euclides da Cunha a sua "poderosa linguagem" ${ }^{20} \mathrm{e}$ valorizava no escritor o humanismo, destacando que ele defendia "o princípio do humanismo clássico", isto é, do "homem em primeiro lugar". ${ }^{21}$

Pela questão do humanismo, verificava a presença de um ideal em Euclides que o fazia agir unicamente a partir de "idéias superiores". Este ponto de partida lhe concedia vantagem para enfrentar as contingências de vida.

O que nos chamou a atenção nesse texto e que nos levou a estudálo foi termos percebido que os valores destacados por Fernando de Azevedo na obra euclidiana são justamente aqueles que ele acreditava ter recebido em sua própria educação, valores estes que ele considerava necessário desenvolver no processo educativo.

Euclides da Cunha constituiu, para o educador, o exemplo de "homem com idéias superiores" e, ao escrever sobre ele, procura ele também se colocar no caminho desse ideal a ser seguido.

Ao escrever sobre esse "intelectual", em 1951, seu pensamento é ainda marcado pela fisiologia, tão presente em $A$ poesia do corpo e em 
trabalhos posteriores. Isso pode ser observado quando, ao descrever o caráter de Euclides da Cunha, indica ter ele no geral forjado seus caracteres, no sentido, até certo ponto, de um equilíbrio perfeito entre os dois centros nervosos que existiam em cada um de nós: "O cérebro, com sua faculdade de associar idéias, de comparar, julgar e concluir, e o simpático neuro-glandular, com suas impulsōes, seus instintos e suas taras" (Azevedo, 1952, p. 176). ${ }^{22}$

$\mathrm{Na}$ concepção de educação e, mais especialmente, de educação física, que defendia em 1915, julgava ser preciso atingir esse equilíbrio para a formação dos caracteres e, apesar de reconhecer que, em muitas ocasiōes, o equilíbrio entre sensibilidade e inteligência se rompia em Euclides da Cunha, ocorrendo a supremacia da sensibilidade extrema sobre a razão, no geral, acreditava que o escritor soubera forjar sua personalidade em tal direção.

No texto de $A$ poesia do corpo e em toda a produção cultural inicial de Fernando de Azevedo, os termos "forjar" e "vigilância" são encontrados reiteradas vezes. Ao falar sobre Euclides, o educador reconhece que este soube exercer vigilância sobre si mesmo; Azevedo reconhecia tal atributo também em si próprio e indicou isso nos estudos autobiográficos ao ressaltar suas qualidades e defeitos.

Ao escrever sobre os traços da personalidade de Euclides da $\mathrm{Cu}-$ nha, chamou-nos a atenção como, no geral, as qualidades e virtudes observadas no escritor eram as que ele reconhecia em si mesmo e que eram ressaltadas em sua educação familiar e no ensino "aristocratizante" dos jesuítas.

Algumas dessas qualidades eram: timidez, ternura, humildade, altivez, modéstia, reserva. ${ }^{23}$ As virtudes destacadas eram: a probidade impecável, o perfeito cavalheirismo, a nobre retidão, a superioridade da energia sobre a fraqueza. ${ }^{24}$ Também a altivez, o sentimento do dever e de honra e a honestidade.

Reconhecia que Euclides, apesar de sua estatura baixa e constituição franzina, possuía a energia viril, presente no aprumo da atitude, no olhar e na expressão e, com relação ao temperamento, considerava ser instável e impulsivo, cheio de impaciências e de rebeldias, ${ }^{25}$ e, mais ainda, que ele possuía uma nervosidade excessiva e extrema suscetibilidade ligadas ao temperamento constitucional, que se agravavam pelo seu estado de saúde e constantes fadigas e atribulações; destacava ainda 
A poesia do corpo: a defesa de uma moral austera

na personalidade de Euclides da Cunha o que chamava de assombrosa energia moral, que muito admirava, assim também como a vida severa e ascética.

Concordava com a afirmação de Euclides, no sentido de que "venceu por si só, sem reclames, sem patronos, sem a rua do Ouvidor e sem rodas", ${ }^{26}$ e o identificava como sendo: tímido, arisco, respeitoso, revoltado diante da "mediocridade triunfante", amante da solidão, sincero, leal, tendo horror ao frívolo, ao banal, ao ridículo, à hipocrisia, à lisonja.

Se tirarmos a nervosidade excessiva e a extrema suscetibilidade combatidas por Fernando de Azevedo, em sua concepção de educação e de educação física, pois levavam a um desequilíbrio, todas as demais "virtudes" que ele indicava em Euclides da Cunha, conforme seus estudos autobiográficos, foram cultivadas por meio da educação que recebeu, eram valorizados por ele, no nível pessoal, assim como no nível mais amplo do próprio processo educativo.

Lembra Azevedo o fato de Euclides da Cunha ter percebido, no contexto da Regeneraçáo carioca, o ambiente da cidade como corrupto e corruptor, destacando a presença dos desfibrados e medíocres, assim como estar a sociedade brasileira nessa conjuntura atravessando um grande desalentador" ${ }^{27}$

Ao escrever $A$ poesia do corpo, Azevedo utilizou-se da crítica feita na conjuntura da Regeneração carioca por Euclides da Cunha. A própria expressão "desfibrado", como dissemos anteriormente, é utilizada por Azevedo no prefácio de A poesia do corpo.

Com relação ao pessimismo percebido em Euclides da Cunha, reconhecia ele nesse texto não ser "daqueles que costumam desenvolver-se nos períodos de decadência ou nas grandes crises sociais, em que se geram ou florescem as doutrinas pessimistas" (Azevedo, 1952, p. 182).

Explica ele que o pessimismo de Euclides da Cunha, que acreditamos atuou sobre a sua formação, "estava antes ligado a essa insatisfação de necessidades, dos desejos, de aspirações e de ideal que implicam o próprio progresso e a crença no progresso, de um lado, e, de outro, as oposiçôes e dificuldades que se levantavam, por toda parte, aos seus ideais e impulsos de renovação" (idem, ibid.).

Euclides da Cunha, em cartas enviadas a amigos nos anos de 1905, 1906 e 1907, considerava a mocidade despreocupada e frívola, 
formada por jovens desfibrados e imbecis, reinando entre eles e o povo em geral um clima de desinteresse pelos problemas fundamentais do país. As denúncias de Euclides da Cunha formuladas no contexto da Regeneração carioca vão estar presentes, em 1915 , no texto de $A$ poesia do corpo, no qual Fernando de Azevedo fez uso do mesmo tipo de raciocínio para pensar a sociedade brasileira.

Ainda com relação às qualidades, o educador via Euclides da $\mathrm{Cu}$ nha como sendo um homem de fibra e valorizava nele, também, o aspecto afetivo, reconhecendo ter este desenvolvido "o culto da amizade", na sua concepção antiga, "temperada ao gosto helênico". Azevedo afirma ter cultivado em si próprio o que percebia em Euclides, isto é, a concepção de amizade à antiga, e desse modo se referia a seus grandes amigos, como se pode observar na dedicatória do seu livro Figuras de meu convivio ao grande amigo Antonio Cândido. A amizade foi um valor importante em sua formação e que aparece em muitos trabalhos seus. ${ }^{28}$

Valorizava, também, em Euclides, o "estoicismo na luta", a "delicadez de escrúpulos" e o "desprendimento pessoal". Indica Fernando que, no seu trabalho, o escritor soube desenvolver uma "disciplina ascética", "submetendo-a, tanto quanto lhe era possível, às exigências do espírito positivo".

Destaca ele, ainda, o amor de Euclides da Cunha pela ciência, o seu esforço científico, pelo seu valor social e pela sua utilidade, sem dogmatismos e exclusivismos, sem deixar de amar as letras e as artes, com permanente inquietação do espírito e curiosidade universal por todos os problemas humanos.

Reconhecia, ao escrever esse texto, em 1951, ser a história dos grandes homens, como Euclides da Cunha, importante para a educação da juventude. ${ }^{29}$

\section{Monteiro Lobato}

Como já destacamos em outra parte deste texto, percebemos ter sido também Monteiro Lobato (1882-1948) um autor importante para Fernando de Azevedo no início de sua produção cultural.

Ambos foram contemporâneos, sendo Fernando de Azevedo apenas 12 anos mais jovem que Lobato, e começaram a escrever mais ou menos na mesma época, tendo sido, inclusive, amigos. 
A poesia do corpo: a defesa de uma moral austera

A importância da literatura de Lobato não se manifestou apenas no primeiro livro de Fernando de Azevedo, marcando acentuadamente toda a sua produção cultural.

Sintetizando, podemos dizer, o Lobato que foi importante para a formação de Fernando de Azevedo foi o do "Jeca Tatu", o da "pedagogia da boa higiene", o do "filão nacionalista", enfim, também aquele que se preparava para a elaboração do "Jeca Tatuzinho". ${ }^{30}$

\section{Reconsiderações sobre o rebaixamento moral}

Retomando a nossa reflexão, procurando interpretar ainda mais as colocações que faz Azevedo sobre como via a sociedade brasileira em 1915 , conforme destaca no prefácio de $A$ poesia do corpo, parece-nos que ele identificava a existência de certa crise de energia na sociedade brasileira, que ele acreditava estar atingindo a vida intelectual, no nível do sentimento e da vida volitiva.

Localizamos um texto seu escrito em 1921, que nos ajuda a explicitar muitas de suas inquietações de 1915, onde podem ser observadas principalmente suas posiçōes, mencionadas na colocação que transcrevemos anteriormente, do Prefácio de $A$ poesia do corpo, quando ele faz a crítica do rebaixamento do nível moral no país. Trata-se de um discurso de paraninfo, proferido em 18 de novembro de 1921, na solenidade de formatura dos bacharelandos do Ginásio Anglo-Brasileiro, de São Paulo, publicada com o título "A cultura da energia" no livro A educação e seus problemas (tomo II, Obras Completas, vol. VIII).

Esse texto, supomos, esclarece a questão já presente em 1915, implicando o seu reconhecimento - dentro do quadro mais amplo da "crise" que atravessava a sociedade brasileira - da existência simultânea de uma "crise de energia".

Julgamos que essa temática vai se tornar ainda mais explícita nos trabalhos que se seguem ao seu estudo $A$ poesia do corpo. O texto em questão permite compreender como, em 1915, Fernando defendia uma "moral mais austera", ao criticar a dominante, que qualificava de epicuréia. A importância da disciplina, numa moral austera, que acreditamos ele defendia, talvez tivesse para o pensador, dentro do seu valor educacional, um sentido mais amplo, encarada como importante na formação da nacionalidade e do "caráter nacional do povo brasileiro", considerado ainda em formação. 
No texto de 1921, podemos clarificar o que ele defendia em 1915, quando via como cabendo à educação e aos educadores, por meio da valorização da disciplina, exercer sobre os discípulos ascendência moral, para atingir o desenvolvimento de "caracteres", "assim como formar espíritos" e "assegurar a ordem e o trabalho". ${ }^{31}$

Nesta linha de pensamento, era necessário desenvolver a vida, a atividade, as forças próprias de cada indivíduo no nível físico, intelectual e moral, assim como no nível da sociedade, isto é, do coletivo, que exprimiria o nível de civilização de um país. ${ }^{32}$ Denunciava, ainda, as "facilidades da vida moderna", já indicando o "aniquilamento da vida mental e moral do país". A educação deveria, no combate à apatia moral, desenvolver hábitos de luta, promovendo a "educação da resistência". ${ }^{33}$

Era, também, muito importante a questão da "educação da vontade" ${ }^{34}$ isto é, a produção da "energia da vontade", levando à educação do esforço que, dentro de uma moral mais austera, exigia o enfrentamento de ações que em si não dão prazer, e que exigem "trabalho e sacrifício", pois o grande mal (ou a grande doença) que ele via no país, em 1915, era o da decadência da energia.

Entendia ele que, no lugar da "moral do prazer", era preciso desenvolver outros valores que pudessem levar à superação dessa crise mais geral, que, no nível intelectual, os indivíduos passassem a pensar por si mesmos e, no nível dos sentimentos, pudessem ter confiança nas próprias forças, por meio da "energia da vontade", combatendo a indolência, a moleza, educando a vontade e, nesse processo, o próprio esforço.

Para o educador, a unidade da personalidade passava pelo equilíbrio da energia nesses três aspectos: cultivo da energia no nível intelectual, do sentimento e da vontade.

Faz uma crítica inicial, em $A$ poesia do corpo, à "cultura livresca" e ao "ensino fundamentado na memorização", 35 parecendo-me que esse tipo de formulação já caminhava no sentido de crítica à "cultura do bacharel".

Defendia Fernando de Azevedo uma concepção de educação que levasse ao equilíbrio entre corpo e espírito. Na crítica que faz à "cultura puramente livresca", talvez já estivesse percebendo, em 1915, o que veio a considerar ser um traço da "cultura brasileira", em 1943, isto é, "literária e de superfície", levando apenas à valorização da abstração, da contemplação. 
Caberia à educação, nessa nova moral que ele indica, "forjar espíritos vigorosos e de boa têmpera", assim como "forjar corpos vigorosos" que teriam também um papel na formação de tais espíritos.

Nessa nova moral, estão fortemente presentes as idéias de sacrifício e de que na vida os caminhos são "ásperos e resvaladios", assim também como a de "dever", que implica a primeira e, ainda, a de "sofrimento", no sentido de que é o sofrimento que "tempera a alma para a resistência".

Defendia ser importante, por meio da educação, o desenvolvimento de capacidades para enfrentar e suprimir obstáculos, considerando resultar o prazer da obtenção da vitória sobre estes.

Considerando a "moral do prazer", definida como "epicuréia", dominante, como sendo egoísta, contrária ao altruísmo, defendia Azevedo, ainda, a educação do esforço, da energia e da perseverança, no sentido do enfrentamento à dor e do trabalho, pois entendia a vida como luta ${ }^{36}$ e que "quem não faz senão eximir-se à dor acaba desertando do combate".

Como já reconhecemos, Fernando de Azevedo, no prefácio de $A$ poesia do corpo, caminha na direção da defesa de uma moral mais austera para o país.

\section{Notas}

1. Jean-Henri Pestalozzi (1746-1827), educador suíço, foi um reformador, no seu tempo, da educação em sentido amplo e da educação física. Seus trabalhos produzidos no início do século XIX (1801 e 1807) fizeram de Pestalozzi um marco da pedagogia dessa época. Suas idéias tiveram repercussão em toda a Europa, em especial na formulação dos princípios para a defesa de uma educação nacional. Fernando de Azevedo, ao lembrá-lo no Prefácio aqui mencionado, parece querer indicá-lo como uma referência dos trabalhos que apontavam para a renovação da educação e particularmente da educação física; ao mesmo tempo que faz essa referência, Azevedo alerta os educadores para que eles não confundam os tempos, querendo expressar, com isso, a necessidade de que o estudo da educação fosse feito com as devidas consideraçōes do tempo histórico, espaço e estrutura. Com relação a Girard, julgamos que o autor se referia a Jean Baptiste Girard, também conhecido por P. Gregoire Gérard, pedagogo suíço de Fribourg (1765-1850), amigo de Pestalozzi.

2. Ver, a esse respeito, Spencer (1887 e 1901), Schützenberger (1850), Worms (1896), Fernandes (1967). Com relação ao estudo do organicismo no Brasil, investigando os "elementos intelectuais decisivos para a formação do Estado Brasileiro", ver Romano (1979; 1982; 1985, p. 113-124).

3. Para uma compreensão do significado da "Escola Positiva", lembrada por Fernando de Azevedo, consideramos importante, ao nível do direito penal, o livro de Basileu Garcia, 
intitulado: Instituiçôes do direito penal (s/d., vol. I, tomo I). Utilizamos a quarta edição desse livro (revista e atualizada: São Paulo: Max Limonad Editor).

4. Escreve, a esse respeito, concordando com um escritor cujo nome não revela: "Anhela-se hoje o prazer, diz um escritor, quando mais se alimentam ternos afetos e sentimentos agradáveis, e as próprias açôes que exigem trabalho e sacrifício não se olham nem se aquilatam, senão pelo prazer que em si têm ou que originam" (Azevedo, 1915, p. 11).

5. Em colóquio com seus alunos, especialmente Antonio Cândido, referia-se Fernando de Azevedo a Bergson como o autor de sua divisa predileta: agir como homem de pensamento e pensar como homem de ação.

6. Vejam-se as considerações que fazem neste sentido Moreira (1982, p. 181), Nagle (1974) e Paiva (1983).

7. Essa expressão demonstra a forma autoritária pela qual esse intelectual e, junto dele, muitos outros desse período viam o pobre. A forma como a pobreza é encarada por Bilac pode ser observada quando ele faz referência às "classes cultas" e aos "homens do sertão", que ele chama de "humildes". Estes aparecem como os não "civilizados", vivendo na "absoluta privação da consciência", reconhecendo que os "homens dos sertões" "não são brasileiros", "nem ao menos são verdadeiros homens", "são viventes sem alma criadora e livre, como as feras, como os insetos, as árvores". Esse tipo de formação e de perspectiva política é que explica, em parte, como mais tarde, em 1924, intelectuais como Monteiro Lobato, Fernando de Azevedo, Plínio Barreto, Renato Jardim, Mário Pinto Serva, Paulo Nogueira Filho encaminham ao então presidente Arthur Bernardes, em 9 de agosto de 1924, carta assinada por mais de 19 pessoas, defendendo o "voto secreto", mas o "voto secreto de censo alto". Esse texto é esclarecedor sobre o elitismo que marcou a avaliação que esses intelectuais faziam de si mesmos. Conforme o entender do grupo, eles representavam "a elite da nação, a sua parte rica, a parte culta, a parte cérebro, a parte nobre por excelência". Ao defenderem o "voto secreto de censo alto", destacam que: "Um vício mortal mantém cada vez mais vivo o divórcio entre o governo e a elite do país, vício tão grave que, não for corrigido a tempo, arrastará o país a completa ruína. Esse vício é o nosso regime eleitoral de censo baixo. A experiência dos povos demonstra que o sistema representativo só dá benéficos resultados quando o regime é de censo alto. Porque o censo alto é o controle da política pela elite da nação, é o respeito à lei feudal de todos os organismos, é a parte cérebro desempenhando suas funções de cérebro e a parte músculo (massa bruta, população, gente rural sem cultura nem capacidade de discernimentos) subordinada naturalmente ao cérebro. As várias eleições a que quase assisti assombraram-me". Essa carta, contida em Carone (1973, p. 128-133), revela que as auto-avaliaçôes dos intelectuais mencionados caminham na direção da "fantasmagoria orgânica", detectada por Roberto Romano, e também na direção do projeto dos liberais por ele analisados, que indicamos anteriormente, o qual procura estabelecer "um campo laico superior" à massa, criando uma linha de produção das elites dirigentes; é interessante no sentido da indicação de como esses intelectuais atribuíram a si um "poder demiúrgico". Nela o povo aparece por meio da utilização de metáforas organicistas como sendo: "músculo" "massa bruta", "boçal", "incapaz de dever cívico", "sem capacidade natural do voto, sem cultura, inteligência, discernimento, multidão ignara". As "elites" e dentro dela os "intelectuais", representavam a "parte cérebro", a "parte nobre". O povo, na qualidade de "músculo", "massa bruta", deveria estar subordinado ao cérebro (os intelectuais e demais "homens de bem", de "censo alto", que deveriam, como "elite da nação", controlar a política, pois representavam as partes "conscientes da nação". O povo como "músculo", "massa bruta" era inconsciente, inculto, sem discernimento e imbecil; para uma com-

Disponível em <http://www.cedes.unicamp.br> 
A poesia do corpo: a defesa de uma moral austera

preensão das categorias utilizadas nessa carta por esses intelectuais, ver: Locke (1971 e 1966); as obras já indicadas de Roberto Romano e também de Franco (1978 e 1980), Capelato \& Prado (1980) e Capelato (1986 e 1988).

8. Na utilização dessa "fantasmagoria orgânica" que, conforme indicamos anteriormente, por meio de Roberto Romano, tem como "núcleo a consideração do problema social brasileiro como doença", reconhecemos ser Olavo Bilac privilegiado na elaboração de "metáforas médicas", pois, conforme dados biográficos, foi estudante de medicina. Como indica Alfredo Bosi, no estudo que faz de Bilac no livro História concisa da literatura brasileira (2. ed. São Paulo: Cultrix, 1974), ele "começou Medicina no Rio de Janeiro e Direito em São Paulo, mas não terminou nenhum curso" (p. 254), dedicando-se ao jornalismo e à literatura, principalmente à poesia. Declara Bilac, nesse texto a que estamos fazendo referência, ter escrito seus primeiros versos quando era estudante da Faculdade de Medicina. Reconhece, ainda, que sua poesia nasceu da "ânsia de saber e da revelação da dor e da piedade" (p. 124). Acreditamos que, embora, em geral, utilizasse "metáforas médicas" em seus textos, nesse a que estamos fazendo referência isso aparece de uma forma ainda mais acentuada, o que deve ter ocorrido por ter sido escrito para uma conferência para estudantes de medicina. É interessante como a utilização do câncer como metáfora é intensa em épocas de crise. Tal imagem, usada em 1915 por Bilac, assim como por outros intelectuais do período, é utilizada ainda em 1995 nos discursos políticos, para indicar graves problemas sociais, assim como a idéia de que estamos atravessando uma profunda crise. Determinadas doenças consideradas mais "perigosas" têm sido utilizadas em determinados contextos históricos dentro da "fantasmagoria orgânica" para indicar o nível de intensidade das "crises" sociais brasileiras, por meio de um discurso "preventivo", "profilático" e "regenerador". Atualmente, a AIDS é muito lembrada.

9. A idéia de estar a sociedade "depauperada", conforme indica Bilac nesse texto, julgamos vai na mesma direção que Fernando de Azevedo percebia no Prefácio de $A$ poesia do corpo, utilizando a expressão "desfibrada".

10. Conforme indicaremos posteriormente, isso não escapou a Fernando de Azevedo. Quando reconheceu, em 1915, a questão do "rebaixamento do nível moral", a exemplo de Bilac, destacava também os vícios, as fealdades. Esse termo parece-nos ter sido muito utilizado na literatura desse período.

11. Conforme afirmamos anteriormente, não pretendemos realizar um estudo aprofundado sobre as influências literárias recebidas por Fernando de Azevedo por ocasião de sua emergência como intelectual. Nessa parte, a exemplo de Bilac, estaremos apenas indicando em que sentido consideramos Coelho Neto uma presença importante no início da produção cultural de Fernando de Azevedo.

12. Lembra Dantas, também nesse artigo, que entre as campanhas culturais do escritor pelos jornais destacava-se a que resultou no Conservatório Dramático (para formação de atores - lembra que entre os alunos mais conhecidos de Bilac destacava-se Procópio Ferreira). Indica que Coelho Neto participou da idéia da criação do Teatro Municipal e da Academia Brasileira de Letras.

13. Esse autor destaca ter se tornado Coelho Neto (1864-1934), "passados pouco mais de dez anos" após a Proclamação da República, uma das "personalidades mais eminentes", o que nos faz reconhecer que sua "desilusão" com o novo regime tenha durado pouco. Com a "fissura" ocorrida no grupo intelectual, Coelho Neto deixou de representar a tendência que assumiria a "tradição engajada da geração de 70 ", situando-se como pertencentes à tendência que assimilou a nova sociedade, à camada dos vencedores, "o filão letrado que se solda aos grupos arrivistas da sociedade e da política, desfrutando a partir de então de enorme 
sucesso e prestígio pessoal, elevados a posiçóes de proeminência no regime e de guias incondicionais do público urbano" (p. 103). Faria parte então da nova camada dos "plenamente assimilados à nova sociedade, os favorecidos com as pequenas e grandes sinecuras, os hábitos das conferências elegantes e dos salōes burgueses, de produção copiosa e bem remunerada. Autores da moda porque assumem o estilo impessoal e anódino da 'Belle époque" (p. 103-104).

14. Fundada no Rio de Janeiro em 1897. Sevcenko (1983, p. 94) indica ser no contexto da Regeneração, mais especificamente em 1905, que a Academia Brasileira passou a ser realmente considerada uma "grande instituição das Letras", passando inclusive a ter sede própria.

15. Ao escrever sobre essa conjuntura e suas lutas pela entrada na Academia Brasileira de Letras, o que vai se consumar apenas em 1961, o próprio título que dá a esse capítulo: "A consagração de uma vida literária" (Parte sétima, Cap. IV), indica como sua volta ao passado que ele via isso como realmente uma "consagração". Acreditamos que já em 1923 entendesse assim sua entrada para a Academia e que lutou por essa "honraria", embora procure, em suas memórias, destacar que sua ética o impedia de disputá-la, de lutar por ela. Escreve, neste sentido, nesse capítulo: "Nunca disputei honrarias e distinçôes nem mesmo cheguei, em qualquer momento, a acariciar, em silêncio, a idéia de recebê-las. Rondaram-me muitas vezes sem conseguirem despertar-me qualquer interesse por elas. Não havia nessa atitude sombra de descaso ou orgulho. Tendo tido educação religiosa, em um lar em que nunca teve morada nem esteve de passagem a vida de, já me bastava isso para não me sentir atraído por qualquer espécie de honraria. Mas, além de minha formação em casa, no convívio de uma santa mãe, e de um pai sem ambições e de hábitos simples ainda quando lhe sorria a fortuna, minha educação em um colégio de jesuítas, no Colégio Anchieta, em Nova Friburgo (estado do Rio de Janeiro), reforçou-me esses sentimentos de fazer o bem, pelo bem, de trabalhar e lutar, sem outra compensação que a vitória de nossos princípios, propósitos e ideais. Se já bastava a atmosfera espiritual e moral em que vivia, em casa e no colégio, para não me alimentar o gosto de tudo o que pudesse satisfazer a vaidade, uma outra fase de minha vida, da adolescência à mocidade, os cinco anos de vida religiosa na Companhia de Jesus, iriam por um remate, se não a todas as cousas terrenas, ao menos a duas delas, os bens materiais e o interesse por compensaçôes e retribuiçôes. Foi daí, dessa sequiência ininterrupta de formações orientadas nas mesmas bases e sob a mesma direção espiritual, que adquiri, sem o procurar, esse desprendimento ou esse desinteresse por quaisquer compensaçôes materiais ou honoríficas de meus trabalhos e de minhas lutas. $\mathrm{Na}$ vida religiosa me firmei no que aprendera ou pressentira que tudo é vaidade. Vanitas Vanitatum et omnia vanitas. Vaidade das vaidades e tudo vaidade. Não tinham muito sentido para mim honrarias e distinçôes. E não sã por isso, por esse desencanto em face de compensaçôes de qualquer ordem, de não importar com origem ou natureza. Mas também porque, empenhado tantas vezes em campanhas e lutas ásperas, não tinha disposição nem tempo para cuidar de qualquer cousa que não fosse ou não concorresse para vitória de meus propósitos e ideais. Essa vitória, perseguida por todas as formas, as mais dignas e adequadas, era o que importava, não por vaidade, mas pela consciência do dever cumprido e de realização de uma obra de interesse comum, na época ou em futuro próximo ou remoto, de que pressentíamos as necessidades e aspirações" (1971, p. 200-201).

16. No desenvolvimento de nossa análise sobre o primeiro livro de Fernando de Azevedo, isto é, A poesia do corpo, procuramos indicar como a obra de Euclides da Cunha (1866-1909) foi importante nas interpretaçōes que esse intelectual fez do seu país em 1915.

17. Uma reflexão sobre o pensamento de Euclides da Cunha poderá ser feita por intermédio da leitura do livro de Nicolau Sevcenko, Literatura como missão - tensões sociais e criação cultural na Primeira República (São Paulo: Brasiliense, 1983). Veja-se o Cap. II do livro

Educ. Soc., Campinas, vol. 27, n. 94, p. 13-46, jan./abr. 2006

Disponível em <http://www.cedes.unicamp.br> 
A poesia do corpo: a defesa de uma moral austera

desse autor: "Euclides da Cunha e Lima Barreto: sintonias e antinomias" e o Cap. IV: "Euclides da Cunha e o círculo dos sábios". Nesse último capítulo, o autor faz um estudo do pensamento desse intelectual, estudando a questão da linguagem, a sua obra e os fundamentos sociais que marcam seu pensamento. Veja-se também: o livro coordenado por Roberto Schwarz, Os pobres na literatura brasileira (São Paulo: Brasiliense, 1983), o trabalho de Walnice Nogueira Galvão, "Uma ausência: Euclides da Cunha" (p. 51-53). E, ainda, de Walnice Nogueira Galvão, a primeira edição crítica de Os sertôes (São Paulo: Brasiliense, 1985); de Dante Moreira Leite, O caráter nacional brasileiro: história de uma ideologia (São Paulo: Pioneira, 1976), o Capítulo II: "Grandeza e miséria dos sertōes" (p. 201-214). De Alfredo Bosi, História concisa da literatura brasileira (São Paulo: Cultrix, 1974, Capítulo VII: "Pré-modernismo e modernismo").

18. Referia-se ao interesse que esse intelectual possuía em pesquisar o trabalho de Euclides da Cunha. Francisco Venâncio Filho escreveu o texto: "Euclides da Cunha" (Rio de Janeiro: Academia Brasileira de Letras, 1931). Lembra Fernando de Azevedo ter sido sobre Euclides da Cunha as últimas conferências feitas por Francisco Venâncio Filho, falecido em 12 de agosto de 1946, "na derradeira peregrinação religiosa, a caminho de São José do Rio Pardo - a Meca do euclidianismo, como lhe chamava" (p. 172).

19. Afirmava Fernando de Azevedo: "Nenhum outro se empenhou tão a fundo e com tanto calor e paixão na penosa tarefa de redescobrir e revelar Euclides e sua vida - pois que sua obra cruzara o espaço com a rapidez e as fulguraçôes de um relâmpago - e mostrar, com a força de um exemplo impressionante, o papel dos grandes homens que são a um tempo inspiradores e modelos de existência ideal. Nenhum outro, entre tantos ilustres e devotados euclidianos, se dedicou com mais zelo e pertinácia a pesquisas de toda ordem sobre o homem e o escritor, o militar e o engenheiro, e coligiu e acumulou, com mais tocante solicitude, para abri-la a todos os que o procurassem, a documentação indispensável à plena inteligência e reconstituição da vida de Euclides. Em Venâncio Filho (eis, entre numerosos testemunhos, o de Silvio Rabelo) encontrei o mais minucioso e o mais exato informador sobre a figura por tantos de seus contemporâneos descaracterizada, como é a do militar, do explorador, do correspondente de guerra, do jornalista e do escritor que foi Euclides. Era com generosa hospitalidade que Venâncio Filho me recebia na sua residência. Até quase madrugada não se cansava de falar, de revolver gavetas e armários à cata do documento ou da notação desconhecida, recompondo, com sua palavra animada, a fisionomia psicológica e moral de Euclides, retificando erros de interpretação, corrigindo enganos biográficos, precisando episódios, lembrando anedotas nem sempre bem contadas pelos que se ocuparam da vida daquele que considerava o mais genial dos escritores brasileiros" (p. 171). O autor faz referência ao texto de Silvio Rabelo: "O bom Francisco Venâncio Filho" (O Jornal, Rio de Janeiro, ano 29, 16 mar. 1947). Silvio Rabelo escreveu o trabalho Euclides da Cunha (Rio de Janeiro: Casa do Estudante do Brasil, 1947).

20. Em Azevedo (1952, p. 173), reconhece o autor que a "linguagem serve ao homem não somente para exprimir alguma coisa como para se exprimir a si mesmo; se é um dos instrumentos espirituais que transformam o mundo desordenado das sensaçōes em um mundo de objetos e de idéias", sendo entendida por Azevedo como significando "a libertação do homem"; admirava em Euclides da Cunha "a poderosa linguagem que ele se forjou, para adaptá-las às necessidades de seu espírito e temperamento, à expressão de suas visōes torturadas e de suas terríveis angústias" (p. 173). Destacava Fernando de Azevedo que, tanto numa obra como Os sertôes, assim como em qualquer outra obra, assim como nos seus ensaios ou mesmo "numa carta escrita às carreiras", Euclides da Cunha é "sempre o mesmo escritor a um tempo maleável e robusto, de espírito prodigiosamente lúcido, de sensibilidade excessiva se não mórbida, e imaginação vulcânica, sempre em atividade e 
pronta para as grandes erupções e descargas emocionais. Nessas belíssimas páginas, e em tantas outras, ricas de substância, de um vigor, de um poder de evocação, de uma faculdade épica e de uma ciência e segurança notáveis, e em que sã se apanha o essencial, sem detalhes ociosos, sem imagens parasitas e sem essas repetiçóes em que se acusam tão freqüentemente as fadigas dos escritores, surge sempre, em corpo inteiro, com seu estilo cintilante, pitoresco e atormentado, o mesmo homem que se move nas alturas, em luta com a própria natureza e a realidade exterior, numa atmosfera saturada de eletricidade" (p. 174). Destaca, ainda, que: "O que mais fortemente lhe repercutiu na obra, não foram, por certo, as idéias, atitudes e tendências das elites burguesas, de seu tempo, em cujos quadros abriu uma brecha, com o ímpeto de uma explosão, mas a força nativa de seu povo, da gente do interior, e da grandeza desnorteante de seu país, contraditório e desordenado” (p. 174).

21. Escreve: "Engenheiro e militar, explorador e cartógrafo, foi nas letras, em contato com a poesia e o drama, o ensaio e a história, que ele encontrou recursos para ultrapassar a profissão e tornar viva a ciência que acumulou, trabalhando com o vasto material que fornecia, como um instrumento de análise e criação; foi nesse convívio com a literatura universal que se lhe desenvolveu o sentido poético e se lhe aguçou esse espírito de finura que, para o humanismo, vale mais que o da geografia; foi, retemperando-se nessa fonte e colocando-se a essa luz sempre nova, que 'descobriu, como diria Marrou, as paixões do homem e seu coração profundo e adquiriu assim uma certa experiência psicológica, um sentido afinado dos valores morais, do real e do possível, do homem e da vida" (op. cit., p. 175). E ainda: "Em nosso século de inquietação, em que, ao princípio do humanismo clássico, isto é, do “'homem em primeiro lugar', já ameaçava suceder a aspiração de 'a máquina antes de tudo'; nessa dispersão constante em que se dissipa o melhor de nós mesmos e o nosso tempo se retalha como sob os dentes de uma máquina de picar, teve Euclides o cuidado paciente de cultivar o seu campo, de juntar seus feixes de trigo e de recolher ao celeiro sua farta colheita. Com sua simpatia humana e sua capacidade de admirar, fez saltar da rocha de uma vida agreste e dura essa provisão de entusiasmo que lhe permitiu, entre ásperas dificuldades, erigir um monumento cuja maior beleza consiste em refletir a unidade de sua vida profunda, na diversidade extrema das contingências. Conservou-se sempre ele mesmo, através de lutas e provações em que soube manter a elevação de sentimentos, o refrescamento do ideal que os abalos emotivos produzem em nós e, como tinha provisões seguras de inteligência, energia e conhecimento, pôde responder quase sempre com vantagem ao choque das emoçôes. Indiferente ao ruído e aos sucessos mundanos, sem intriga e sem ambiçōes, ligado unicamente a idéias superiores, não sã enfrentou o temporal que tantas vezes lhe rugiu às portas da casa, e acabou por reduzi-la a ruínas, como sabia arrostar a bonança que, para os navios, como para um homem do seu temperamento, é às vezes mais perigosa do que a tempestade. Mas Euclides sabia que o homem luta com suas qualidades, quando as tem, mas sobretudo com os seus defeitos; e, tendo-as tantas e em tão alto grau, os defeitos não participavam menos de suas lutas, vitórias e derrotas" (op. cit., p. 175-176).

22. Azevedo apóia-se, nessa colocação, em Ch. Fiessinger que, segundo reconhece, estudou a formação dos caracteres, "retomando a linha dos grandes moralistas do século XVIII".

23. Escreve: "Associam-se, alternam-se ou se chocam a timidez e a impetuosidade, a ternura e a veemência, a humildade e a altivez, e, aos cuidados, incertezas e dúvidas sobre o próprio valor, sucedem-se desabafos de confiança em si e nos outros, como a depressão ao entusiasmo, as esperanças, aos desfalecimentos” (p. 176-177).

24. Escreve: "Mas esse homem estranho que, na sua modéstia, se inquieta e se aflige, diante da competição da mediocridade afoita que se acotovela na disputa de cargos, preferências e honrarias; que nunca perdeu, segundo ele mesmo o confessa, a reserva e a timidez (...). Como todos os homens de bem e todas as grandes almas, Euclides defende-se menos com 
A poesia do corpo: a defesa de uma moral austera

os seus defeitos do que com os seus méritos e virtudes, tomada essa palavra virtude sobretudo no sentido etimológico e o mais verdadeiro que tem em latim o vocábulo virtus, e, italiano, virtú, especialmente na época da Renascença. Proveniente de vir, homem, como, entre nós, virilidade, o poder efeito e eficaz de um homem é o total de que ele vale na luta. Salústio não apresenta nenhum de seus personagens sem lhe avaliar a força pela superioridade do que ele tem de energia sobre o que tem de fraqueza, e aprecia ao justo a virtus de Catilina, que é um homem cheio de defeitos, vários dos quais contam na balança de sua virtus e de seu valor individual. Em Euclides, porém, a virtude não sã exprime a varonilidade, a virtus latina ou a virtú do italiano do Renascimento, mas a virtude, no sentido mais largo, a probidade impecável, o perfeito cavalheirismo e a nobre retidão" (p. 177).

25. Escreve: "Como todo grande homem, tem alguma coisa de desmesurado e excessivo, e em nada se parece com o gênio ocidental que, considerado nas suas mais nobres criaçóes, comporta sempre não sei que de medido, de temperado e de equilibrado. Gênio da raça, a um tempo místico e real, Euclides, como ele mesmo se reconheceu, 'foi um ser enigmático, verdadeiramente incompreensível entre os seus contemporâneos'” (Azevedo, 1952, p. 179-180).

26. Fernando de Azevedo indica estar essa colocação em Euclides da Cunha a seus amigos (p. $62,55,213,84$ e 85$)$

27. Afirma Azevedo (1952, p. 181-182): "Tudo o que se lhe deparava aos olhos o espetáculo desolador da cidade, com seu ambiente corrupto e corruptor, com a trama vil de suas intrigas e a brutalidade das competiçôes sem freios, com sua récua de desfibrados e medíocres e a legião inumerável de espertos e malandros felizes acotovelando-se por toda parte, sacudia-lhe e irritava-lhe os nervos e o fazia descambar a todo o momento para esse pessimismo que ele mesmo qualificava de desalentado, de abominável ou de incurável, e se exprimia em confidências amargas e desabafos desesperados". Indica: "O Rio de Janeiro, quando apenas começava a despojar-se de sua vestidura colonial para se transformar, com Pereira Passos, numa metrópole moderna, como a viu Euclides?”. A vida entre nós mudou, escreve a Domício da Gama: "Há um delírio de automóveis [isto em 1907], de carros, de corsos, de recepçōes, de conferências, que me perturba e me atrapalha, no meu ursismo incurável. Dá vontade da gente representar a ridícula comédia de Catão, saindo por essas ruas, de sapatos rotos, camisa em fiapos e cabelos despenteados. Que saudade da antiga simplicidade brasileira!" (p. 187). Mostra também que: "De volta de sua expedição ao Purus, em que pensaria Euclides? A minha maior aspiração [escreve da cidade maravilhosa a Alberto Rangel] seria deixar de uma vez esse meio deplorável, com suas avenidas, seus automóveis, os seus smarts e as suas fantasmagorias de civilização pesteada". Não se conforma com a vida da cidade em que parece sofrer de um desajustamento irremediável. A Rangel confessa-se desolado "com a pasmaceira trágica que há nesse país que esperneia, galvanizado, na Praia Vermelha e morre de fome nos sertōes" (p. 192).

28. Em Azevedo (1924, p. 97 a 106), o autor publicou um texto que tem como título: "A amizade antiga".

29. Escreve: "Neste tempo tão cheio de obscuridades e incertezas, de tortuosidades e misérias, se quisermos, de fato, assentar na educação da mocidade as noçōes e virtudes morais, e elevar ao primeiro plano o cuidado da dignidade e da honra, não temos nada de melhor do que seguir a mais intensa de todas as luzes - aquela que brilha de todas as partes na vida dos grandes homens aos quais se reuniu esse 'pioneiro da nacionalidade triunfante', esse gênio da raça, na sua existência, desigual e revolta, como a nossa própria natureza, feita de doces planuras e de relevos absurdos, de forças hostis e dispersivas, mas também de poderosas forças de atração" (p. 195). 
30. Veja-se o trabalho de Marisa Lajolo, "Jeca Tatu em três tempos", publicado no livro organizado por Roberto Schwarz (1983, p. 101-105). Nesse texto, a autora estuda as posiçóes ideológicas de Monteiro Lobato, de 1914 a 1947. Mostra como o "Jeca Tatu" aparece na produção de Lobato em 1914, com o artigo "Velha praga", que alcançou grande repercussão por ter sido citado e comentado por Rui Barbosa, quando candidato civil à Presidência da República. Rui Barbosa escreveu "a peça oratória": "A questão social e política no Brasil", feita em 20 de março de 1919 no Teatro Lírico do Rio de Janeiro. Trecho dessa "peça oratória" foi publicado no livro Urupês, de Monteiro Lobato. Em seguida, analisa como, dez anos depois, aparece o "Jeca Tatuzinho" (que circulou no Almanaque de Produtos Farmacêuticos Fontoura) e, em 1947, o "Zé Brasil". Veja-se, no livro de Dante Moreira Leite (1976), o Capítulo II: "Grandeza e miséria dos Sertōes", particularmente as páginas 211 a 214. Veja-se, ainda, Cândido (1965), Bosi (1974), Sevcenko (1983) e Brasil (1957).

31. Em 1921, ele definia a disciplina a partir de Pécaut. Escreve: "A disciplina verdadeira, na fórmula exata de Pécaut, é um conjunto de meios destinados nã̃o sã a assegurar a ordem e o trabalho, mas a formar caracteres, como a instrução tem por fim formar espíritos. Não se formam nem uns nem outros como se talham pedras. Caracteres e espíritos são vivos" (Azevedo, 1958).

32. Em 1921, no texto "A cultura da energia", essa questão relativa ao nível de civilização de um país e ao papel que acreditava ter nesse processo a educação (questão presente também em 1915) é colocada de uma forma mais explícita, recorrendo a Nietzsche. Escreve, neste sentido, em 1921: "Se o nível de civilização de um país é determinado, como se exprimiu Nietzsche, 'não sã pelo grau de independência de um indivíduo em face dos outros, mas também pelo desenvolvimento intrínseco destes indivíduos', o espírito de iniciativa, cooperação e disciplina, pelo qual se aquilatará o grau de civilização de um país, é o resultado de uma concentração de forças espirituais na formação de um conjunto harmonioso de convicçōes, na medida do sentimento invariável dentro da variedade atormentada das circunstâncias e na firmeza em pautar por esses princípios todos os atos da vida. O que dá ao homem uma fisionomia moral própria, inconfundível, o que lhe imprime à personalidade um cunho viril, é, por certo, o espírito de observação, que o faz conhecer a si mesmo e a realidade; é o equilíbrio do sentimento eqüidistante do otimismo ingênuo, que o faria despregar todas as velas à esperança, e do pessimismo que lhe cortaria as asas a todos os impulsos; é, enfim, a energia da vontade preordenada a traduzir nos atos, que mais esforço solicitarem, os princípios, que a inteligência abraçou" (Azevedo, 1958; indica ser a citação de Nietzsche, da obra Die fröbliche Wissenschaft, v. 178).

33. No texto de 1921, explicitava isso da seguinte forma: "Mas esta mesma simpatia, que vos impeliu a escolher-me para vosso paraninfo, me enraíza a confiança de poder, com minha palavra, despertar em vãs a consciência das necessidades de uma reação contra as facilidades modernas, que são, sobretudo, facilidades dadas ao aniquilamento da vida mental e moral, à idiofobia, ou, em outros termos, à preguiça do espírito. O sucesso da palavra está mais no ouvido de quem a ouve do que na boca de quem a profere (...). Demais, o objetivo primacial que deve ter presente um educador, quando da cátedra ou da tribuna se dirige à mocidade, sempre em perigo de se deixar enlear e tolher na teia da apatia moral, que tende à abolição de tudo o que constitui a personalidade humana, é incutir hábitos de luta, promover a educação da resistência, e criar costumes, que são necessários a uma democracia livre, o sentimento da responsabilidade pessoal e o self-government da consciência" (Azevedo, 1958, p. 14).

34. A educação da vontade ocupa a parte mais importante dos "Exercícios espirituais" de Santo Inácio de Loyola, fundador da Companhia de Jesus.

Disponível em <http://www.cedes.unicamp.br> 
A poesia do corpo: a defesa de uma moral austera

35. Essa questão é bem desenvolvida no texto "A cultura da energia" (1921). Ao escrever sobre essa questão nessa conjuntura, apóia-se em Montaigne, Kant e Max Leclerc, indicando-os como sendo os melhores mestres da pedagogia. Ao citar Montaigne, utiliza o livro de F. Guerix, Histoire de l'instruction et de l'éducation; ao citar Kant, utiliza o trabalho de Paul Duproix, Kant et Fichte et le problème de l'éducation; ao citar Max Leclerc indica seu trabalho: Les professeurs et la société en Angleterre (Colin \& Cie.). Lembra também Descartes por intermédio do trabalho de Alexis Bertrand, "Descartes et l'éducation" (Révue Pédagogique, sept. et oct. 1897).

36. No texto A poesia do corpo, em 1915, assim como em "A cultura da energia", em 1921, Fernando de Azevedo assumiu, dentro dessas temáticas mais gerais, outras duas temáticas: a questão da "ociosidade" e a da "fraqueza". No texto de 1921, o interessante é que não usa, como fez em 1915, a expressão "moral do prazer", mas "hedonismo".

\section{Referências bibliográficas}

AZEVEDO, F. A educação e seus problemas. 4. ed. São Paulo: Nacional, s/d.

AZEVEDO, F. A poesia do corpo ou a gymnastica escolar: sua história e seu valor. Belo Horizonte: Imprensa Official do Estado de Minas Gerais, 1915.

AZEVEDO, F. Jardins de Salústio: à margem da vida e dos livros. São Paulo: Irmãos Marrano, 1924.

AZEVEDO, F. Na batalha do humanismo. São Paulo: Melhoramentos, 1952. p. 171-195.

AZEVEDO, F. A cultura da energia. In: Azevedo, A. A educação e seus problemas. 4. ed. São Paulo: Melhoramentos, 1958. (T. II)

AZEVEDO, F. História de minha vida. Rio de Janeiro: Livraria José Olympio, 1971. p. 201-202.

BILAC, O. Últimas conferências e discursos. Rio de Janeiro: Francisco Alves, 1924.

BOSI, A. História concisa da literatura brasileira. São Paulo: Cultrix, 1974.

BRASIL, Pe. S. A literatura infantil de Monteiro Lobato ou comunismo para crianças. 2. ed. [São Paulo]: Edições Paulinas, 1957.

CÂNDIDO, A. Literatura e sociedade. São Paulo: Nacional, 1965. 
CAPELATO, M.H.R. Os intérpretes das luzes: liberalismo e imprensa paulista: 1920-1945. 1986. Tese (doutorado) - Faculdade de Filosofia, Letras e Ciências Humanas, Universidade de São Paulo, São Paulo.

CAPELATO, M.H.R. Os arautos do liberalismo: imprensa paulista, 1920-1945. São Paulo: Brasiliense, 1988.

CAPELATO, M.H.R.; PRADO, M.L. O bravo matutino, imprensa e ideologia: o jornal O Estado de S. Paulo. São Paulo: Alfa-Omega, 1980.

CARONE, E. A Primeira República: 1889-1930. 2. ed. São Paulo: DIFEL, 1973.

DANTAS, N. Um patrono injustamente esquecido. Revista Brasileira de Educação Física e Desportos, v. 12, n. 53, jan.-dez. 1984.

FERNANDES, F. Fundamentos da explicação sociológica. 2. ed. São Paulo: Nacional, 1967.

FRANCO, M.S.C. John Locke: a propriedade como conceito antropológico fundamental. São Paulo: [s.n.], 1978. (mimeo).

FRANCO, M.S.C. Retórica e método: consideraçōes sobre o progresso da ciência. São Paulo: [s.n.], 1980. (mimeo).

GALVÃO, W.N. Uma ausência: Euclides da Cunha. In: Schwarz, R. (Org.). Os pobres na literatura brasileira. São Paulo: Brasiliense, 1983. p. 31-53.

GALVÃO, W.N. Os sertôes: edição crítica. São Paulo: Brasiliense, 1985.

GARCIA, B. Instituiçōes do direito penal. 4. ed. v. 1, t. 1. São Paulo: Max Limonad, s/d.

LAJOLO, M. Jeca Tatu em três tempos. In: Schwarz, R. (Org.). Os pobres na literatura brasileira. São Paulo: Brasiliense, 1983. p. 101-105.

LEITE, D.M. O caráter nacional brasileiro: história de uma ideologia. São Paulo: Pioneira, 1976.

LOCKE, J. Quelques pensées sur l'éducation. Paris: J. Vrin, 1966.

LOCKE, J. Two treatises of government. London: Evryman's, 1971. 
A poesia do corpo: a defesa de uma moral austera

MOREIRA, S.L. A liga nacionalista de São Paulo: ideologia e atuação. 1982. Dissertação (mestrado em História) - Faculdade de Filosofia, Letras e Ciências Humanas, Universidade de São Paulo, São Paulo.

NAGLE, J. Educação e sociedade na República. São Paulo: EPU/EDUSP, 1974.

PAIVA, V.P. Educação popular e educação de adultos. 2. ed. São Paulo: Loyola, 1983.

RABELO, S. O bom Francisco Venâncio Filho. O Jornal, Rio de Janeiro, ano 29, 16 mar. 1947.

RABELO, S. Euclides da Cunha. Rio de Janeiro: Casa do Estudante do Brasil, 1947.

ROMANO, R. Brasil: Igreja contra Estado. São Paulo: Kairós, 1979.

ROMANO, R. Conservadorismo romântico: origem do totalitarismo. São Paulo: Brasiliense, 1982.

ROMANO, R. Corpo e cristal: Marx romântico. Rio de Janeiro: Guanabara, 1985. p. 113-124.

SCHWARZ, R. Os pobres na literatura brasileira. São Paulo: Brasiliense, 1983. p. 101-105.

SEVCENKO, N. Literatura como missão - tensões sociais e criação cultural na Primeira República. São Paulo: Brasiliense, 1983.

SCHÜTZENBERGER, F. Les lois de l'ordre social. t. 2. Paris: Hingray, 1850 .

SPENCER, H. Educação intellectual, moral e physica. Rio de Janeiro; São Paulo; Recife: [s.n.], 1901.

SPENCER, H. Principes de sociologie. Paris: Felix Alcan, 1887.

VENÂNCIO FILHO, F. Euclides da Cunha. Rio de Janeiro: Academia Brasileira de Letras, 1931.

WORMS, R. Organismes et societé. Paris: V. Giard \& E. Briere, 1896. 